\title{
Intergroup Cohesion and Its Effects on Employees Performance in Schools in Nairobi City County, Kenya
}

\author{
*Mukhwana, Mildred Nasimiyu, and ${ }^{1}$ Dr. Edna Jemutai Moi \\ *Masters Student, Department of Public Policy and Administration \\ ${ }^{1}$ Lecturer, Department of Public Policy and Administration \\ Kenyatta University, Kenya
}

\begin{abstract}
Most organizations have been reporting their inability to achieve the set objectives. Several factors have been pointed out to be the major cause. Apart from other external factors such as adequate finance, political goodwill and conducive environment, there seem to be other factors related to the intergroup cohesion that affect goal achievement. This study was done in schools in Lang'ata Sub County and it sought to establish the intergroup cohesion on employee performance in public schools in Lang'ata Sub County. The study had three objectives, to access how intergroup cohesion affects members' commitment during performance of duties, to examine the effects of intergroup cohesion on task performance and to evaluate various effects of training on employee performance.

It focused on employees who were be selected purposefully. After the study, it was found that intergroup cohesion and its aspects like training, commitment and workload affect employee performance. This implies that intergroup has a lot of effects when it comes to employee's performance and that there is need to improve the team cohesion if we were to enjoy the benefits of teamwork. The study recommends that; there is need for institutions to have a strategic plan to enable it work towards a certain goal while committing themselves in work. This will help employees to remain focused to a certain goal and remain committed into realizing that goal or objective, there is need for institutions to have a well laid program that guides on how tasks should be administered to each group in an organization and need for institutions to take into consideration the new trends in job performance and bring in resource persons who will help train the members for better productivity. Finally, that there is need for institutions to have an elaborate plan which will work towards improving cohesion if maximum performance is to be realized.
\end{abstract}

Key Words: Intergroup Cohesion, Effects, Performance, Employees, Schools, Commitment, Task Performance, Team Work.

\section{INTRODUCTION}

Various studies have been done about organizational settings and majority have shown an increasing emphasis on team processes, systematic structures of leadership, efficient and success in attaining a goal. ${ }^{[1]}$ Group work has been increasing in most organization and it is being taken to be the main cause of success and progress. Indeed, studies shows that group and teamwork have continued to post positive results and outcomes bearing in mind that it increases service delivery, commitment among employees and goal realization. Group cohesion is normally seen as a product of linking people of different social aspects into one group unified under one goal. Cohesion can be seen in four phases being the social, task, unity and emotions. ${ }^{[2]}$ Studies shows that indeed, teams that are cohesive may lead to a high rate of productivity. Austin, (2013) in his study says that cohesiveness in a team leads to greater output meaning that cohesiveness is directly proportional to performance and goal accomplishment. There is a need however to distinguish between group related terms and bear in mind the different areas at which they occur. With this in mind, we can make a difference of cohesiveness in different organizations such as sports. ${ }^{[3]}$

\section{BACKGROUND OF THE STUDY}

According to a study on oil company workers in $\mathrm{UAE}^{[4]}$ proposed in their study in Kuala ${ }^{[5]}$, on matters on entertainment established that group cohesion could influence performance in a certain direction. This implies the need to focus on context of the group. According to a study in Accra Metropolitan ${ }^{[6]}$, companies sometimes are able to enhance their employee rate of 
undertaking a task through team building. ${ }^{[7]}$ In a study in private banks in Mogadishu Somalia, wrote that various effects of intergroup cohesion in increasing performance of the employees during this time of increased rate of competition can -not be assumed. Cohesion in groups improves group's efficiency and rate of performance. He adds that cohesion allows members to have the spirit of possession, and this improves their commitment in task delivery. Teamwork also brings or gives member an opportunity to mix different skills together which has a positive effect of performance. ${ }^{[7]}$

Group pride plays a positive role in situations where the relationship between performance and cohesion are positive and often dependent on success in past performances ${ }^{[8]}$. Overall, the relationship between cohesion and performance has been found to be positive in some studies and negative in other studies, this seeming contradiction confirms the complexity of research in group cohesion (Hornaday, 2014). A group can deploy its togetherness to fight organizational objectives or to support them ${ }^{[2]}$ in their study established that group cohesion could influence performance in a positive or negative direction contingent on the context. This implies the need to focus on context of the group. Casson ${ }^{[3]}$ establishes that cohesion had a negative moderating effect at individual levels but a positive one at group level in competency-performance relationships thus showing that there is need to take a review on the group context. This implies that group cohesion can lead to otherwise high performing members reducing their effort to conform to the group. Within and without the organization (Mulika, 2010). ${ }^{[2]}$ Cited that managers in the current business world are trying as much as possible to assign tasks to employees who have significant opportunities to strengthen and develop their knowledge and relevant skills. ${ }^{[9]}$ Also urged that for optimally task performance, members in a team to respect each other and have trust among them as they still appreciate each one's contribution.

Employee performance can be measured in different dimensions like productivity, job satisfaction, motivation among workers, ability to use new technology and also to adopt to it effectively. The overall management of an organization and its leadership structure should conduct evaluation on its employees on different basis like weekly, monthly etc. to ensure there is continuity in positive performance. ${ }^{[10]}$ Employee performance is concerned with how employees perform their duties in firms or organization. These has to do with various aspects that relate directly or indirectly to the firm's or organizational objectives or the work to be accomplished. ${ }^{[11]}$ Performance appraisal can be used to monitor employee's performance on different basis. This majorly promote the realization or achievement of a goal or objective with effectiveness being considered. Progressive improvement of employees is a goal of every firm and managers do a lot to ensure it succeed in promoting employee's performance. Employees' performance can be seen in terms of teamwork and cooperation, understanding and most importantly, goal realization. ${ }^{[12]}$

Social union in urban areas implies making social orders where individuals have the chance to live respectively with every one of their disparities and then again, the best approach to move toward solidarity and decent variety, and the edges in question, is obscure to authorities ${ }^{[13]}$. Larsen explains cohesion as the popular belief that people in a certain country can share or shares a similar moral direction which eventually turns to be a common trust reference point ${ }^{[2]}$. Cohesion can then be explained and determined by the total number of people who trust one another in a social set up and some extent of degree which can be taken to be like nationality. ${ }^{[9]}{ }^{13]}$ cites that people explores how governmental issues, religion, family, instruction, and financial aspects are utilitarian for a general public, and take into account social union levels of request and solidness set up by the common shared standards and qualities in the public eye. These empowers people to distinguish and add to shared objectives, and offer good and social standards that work as a base for relational connections.

\section{STATEMENT OF THE PROBLEM}

Performance in any organizational set up should always look at involving the employees to offer a suitable forum for them also to understand it and its significance at the workplace. When employees understand the systems of appraisal and also its role, there is a bigger possibility of getting the best performance from the employees. According to Kumar and Kesari 2016, This understanding will help employees in concentrating on the major performance areas keeping in mind the main Key Performance Indicators. Employees need to be guided on how to utilize the scarce available resources with an aim to achieve the set objectives being delivery of various services efficiently. Management of employee's performance need to be a progressive process of being able to manage various activities of different employee so as to make sure performance is realized. (2009/10, 2010: 4).

Various researchers who studied teaching teams found that indeed, there exist a greater evidence that cohesion among members such as educationist groups is associated with enhanced grade results outcomes as well as a higher teacher, student and parent satisfaction ${ }^{[13]}$. Although the prior literature reveals that more focus was on diversity of aspects of performance, it is still important to note that all these greater cohesions also lead to individual fulfillment. Owing to the fact that organizations conduct their roles in an environment which is more complex in structure, dynamic, more competitive and also volatile in nature, it is advised that Human Resource managers should be systematic in their approach to human resources ${ }^{[14]}$. Human Resource managers need to be keen on what they do and not do as everything affects the working environment which can further go into affecting groups and performance of group members in the workplace, motivation, organizational commitment and engagement 
levels amongst other behaviors. This is the background against which this research is founded on, trying to establish, examine and discuss various effects of intergroup cohesion on task performance.

\section{OBJECTIVES OF THE STUDY}

i. To assess effects of commitment on performance in schools in Nairobi city county.

ii. To examine effects of workload performance of employees in schools in Nairobi city county.

iii. To evaluate effects of training on employee performance in schools in in Nairobi city county.

\section{THEORETICAL LITERATURE REVIEW}

The study was anchored on the relational cohesion theory and group process theory. The relational cohesion theory answers questions on cohesion and total commitment in a social set up or social mutual interactions set up. It is important to note that any joint activity carried out has an implication. Relational cohesion theory further brings to light that any structural environment has a way of affecting group emotions and those relations which are cohesion in nature lead to awareness and total commitment. ${ }^{[15]}$ The theory proposes that every member in a unit will seek exchanges that that will in one way improve their gain or output. It proposes that this interaction begins as a single interaction where individuals seek to get an exchange with just one another then it grows to a bigger group. The relational cohesion theory further shows that if exchanges are repeated, they affect emotions, and finally personal commitment. Human beings are self-centered in nature and they will always struggle to make a gain out of others. As they struggle to make the gain, some basic life principles get anchored in a group. This exchange leads to affective and cognitive effects in a group thus increasing the groups interactions as one aim to get more exchanges from one another. More understanding is created, harmony and commitment towards goal achievement.

Group process theory is based upon the group ability to change to various environments both external and internal always provides a perfect understanding on group growth and development. The overall group structure, its nature and the overall group interaction in organizations need to be developed from time to time. A social group is formed through the interactions of one another during the process of service delivery. ${ }^{[16]}$. Continual interaction between employees the day-to-day relationship that are made by offering support to each member in an organization, making valuable decision regarding the development of the organization, solving various argument as well as helping each other in the issues and also complement one another ${ }^{[17]}$.

Group interaction keeps on changing depending on the behavior of the employees. This means that, the external behaviors of the employees in a big way affect the general team interactions. According to Mbinya ${ }^{[18]}$, the change that is manifested in the behaviors of the employees can be accounted for majorly two types of interactions which are relationship type interactions and task type interactions. Task type interaction mainly focuses on the behavior in a certain group which are mainly based on the set goals, strategic plans various projects and the related work. On the other hand, relationship type of interaction is majorly focused on those social and interpersonal aspects of a group life. Group dynamic theorists affirms that indeed, there is a great connection between team behavior and the task intended. In firm or organization point of view, the group interaction that is based on relationship bears and advantage when it comes to the cost and on the other side, the one which is task -oriented bears many benefits.

\section{EMPIRICAL LITERATURE REVIEW}

On stakeholders' commitment, every employee is expected to be committed at work. Commitment may be internally or externally motivated depending on the environment. Intergroup cohesion then plays a big role in ensuring a high commitment among employees. This can happen through mutual communication, encouragement and togetherness. O'Malley, ${ }^{[19]}$ further studies shows that intergroup cohesion affects employee's commitment in several ways. From the moral commitment point, intergroup cohesion aims to look at how employee's cohesion increases morals in an organization which in return affect self -esteem among the members. This means that a strong and positive cohesion will lead to increased commitment and hard work. Employees will have a sense of belonging and as morality increases, other workplace diversity that could have worked in a negative way get eliminated.

Research shows it is through intergroup cohesion that affective commitment arises through sharing, working in groups and supporting one another in the whole process of running an organization. Positive intergroup cohesion will lead to improved affective commitment and hence reduce issues like job absenteeism which will result into improved performance of the 
employees. All of the above studies done reflects on cases on different contexts and none points to specifically Lang'ata Sub County or rather primary schools found in in Lang'ata Sub County which are public as well. Therefore, this research comes in to fill the research gap identified above and open up room for future studies similar to this in different contexts.

Globally, research studies have shown employees have a tendency of adapting to a certain attitude in the organization as derived from the perfection that comes from the task assigned to them in an organization. ${ }^{[20]}$. Employees can as well deal with ambiguous work by having or developing an adaptive schedule of performance. ${ }^{[21]}$.

In Nigeria for example, innovation and growth requires employees to take up new lessons in developing skills to be able to adapt to the new changes in and effective way, ${ }^{[22]}$.

Research have been carried out in the developed and the developing nations to investigate the various effects of teamwork on performance of employees. The success of the goals, plans need to be clear, and employees need to be self-motivated and be accountable at every aspect. The above also will guide the researcher in identifying various aspects of workload and link them to the specific context of employees in government owned schools in Lang'ata Sub County.

Globally, various research studies show that indeed, training is normally developed and enhanced by use elaborate programs and means aimed imparting employees with the best skills essential in the current job market. World Bank, (2011). This means therefore, that it is critical to keep in mind that needs of the employees need to be considered during stages of planning to get the best results. Farooq in his study shows that training to foster development of the performance of employees need to be facilitated since they help improve workplace projects. It also shows various advantages of offering training to the development of workplace. He affirms and stresses on the use of technology in an organization if the organization has to fulfill its objectives.

Regionally, various research studies show a similar aspect as at the global perspective whereby employees are taken to be a vital resource of any organization, for the achievement or success and failure of institution relates to how the employees perform their tasks. This should therefore be a key reminder of the role played by training in ensuring performance is a success, ${ }^{[23]}$

The above research will be of more importance to the researcher since it will help in identifying training aspects in the changing world. Due to globalization and growth in technological advancement, there is need for employees to get in service training on various technological and digital skills and therefore our research will aim to look at how the training affect cohesion which affects productivity at the end. This research will also be different in that it will be conducted in Kenya and specifically in Lang'ata Sub County and this will give a good comparison of what have been studied in other areas and our areas as well.

\section{CONCEPTUAL FRAMEWORK}

Independent variables

Dependent Variable

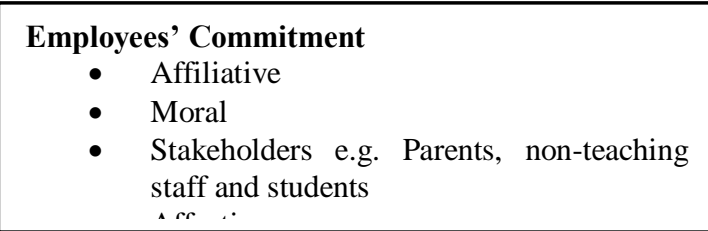

Employees' Workload

- Quantity of workload

- Ratio of teachers to students

- Group stability

- Desire for group success

Employees' Training

- On job skills

- Materials for training

- Training in use of technology

- training on peace and stability.

Figure 1 Conceptual Framework 
International Journal of Advances in Scientific Research and Engineering (ijasre), Vol 7 (11), November -2021

\section{RESEARCH METHODOLOGY}

The study applied the descriptive research design. Research design helps the researcher during the process of explaining or rather describing the data collected and this can be done using pie charts, tables, inferential analysis among others. The use of descriptive research design enabled the researcher to be able to describe various characteristics and features of objects, people, target groups, organizations, institutions, or environments. It further looks at the different questions concerned in research. The location of the study area was Lang'ata Sub County in the County of Nairobi. Nairobi County has an estimate of 4.23 million people. (KNBS, 2019), distributed in an area of 696 square kilometers. Lang'ata Sub County is located at approximately $1^{\circ} 22^{\prime} \mathrm{S}$ and $36^{\circ} 44^{\prime} \mathrm{E}$, in an area of $197.80 \mathrm{Km} 2$. The study was selected because it will help in improving human capital as a resource in different teams which is essential for the best performance in organizations in the same or different lines and no other study of this nature had been carried out in this study location. In the process of data collection, the study used different techniques to collect data such as the use of interview guides and semi structured questionnaires. The two were used to ensure there is quality results after the results. The population for this study consisted 265 employees from government owned public schools in Lang'ata Sub County.

Both quantitative and qualitative data were simultaneously collected, analyzed separately for the purpose of establishing the facts. After collecting data, it is important to edit the data with the intention of obtaining the best and accurate data. When this is done, errors which may have occurred during the research may highlighted and corrected, ${ }^{[24]}$. Before the analysis of the data, we took a keen interest on its completeness as well as its correctness. This study applied inferential and descriptive technique to analyze data collected. The results were then presented using tables of frequencies, graphs, and pie charts. Data analysis was aided using (SPSS v. 24).

The collected data was tabularized and categorized according to their shared features. Secondary data were acquired from an assortment and review of unpublished and published materials, academic papers, periodicals, and journals. A multiple regression model of the form below was used: $Y=\beta_{0}+\beta_{1} X_{1}+\beta_{2}+X_{2}+\beta_{3}+X_{3}+\square$

\section{RESEARCH FINDINGS}

The background of respondents indicates that they covered a variety of characteristics of employees in public schools. This study sought to establish and analyze how intergroup cohesion affects employee's performance in schools in Lang'ata Sub County. The researcher aimed at a population of 249 accounting for (100\%). During the actual research, 19 questionnaires were not returned, and this made the total respondents to 230 .

\section{Descriptive analysis of Commitment on employee performance}

The research study sought to identify or establish how commitment affect the general employees' performance in schools in Nairobi City County as the first objective. A good number of the respondents showed that indeed commitment has a positive effect on employees' performance. It was also noted that members of an organization tend to be more committed when working as a team or when working in a group. This can be clearly reflected in a study on how teamwork impact performance who clearly shows that if a group work together, ${ }^{[4]}$ productivity increases due to the increased rate of commitment. As represented in the figure below, when there is team work, there is an $85 \%$ possibility of desired outcomes as opposed to individual commitment which only results to $15 \%$ of desired outcome. 


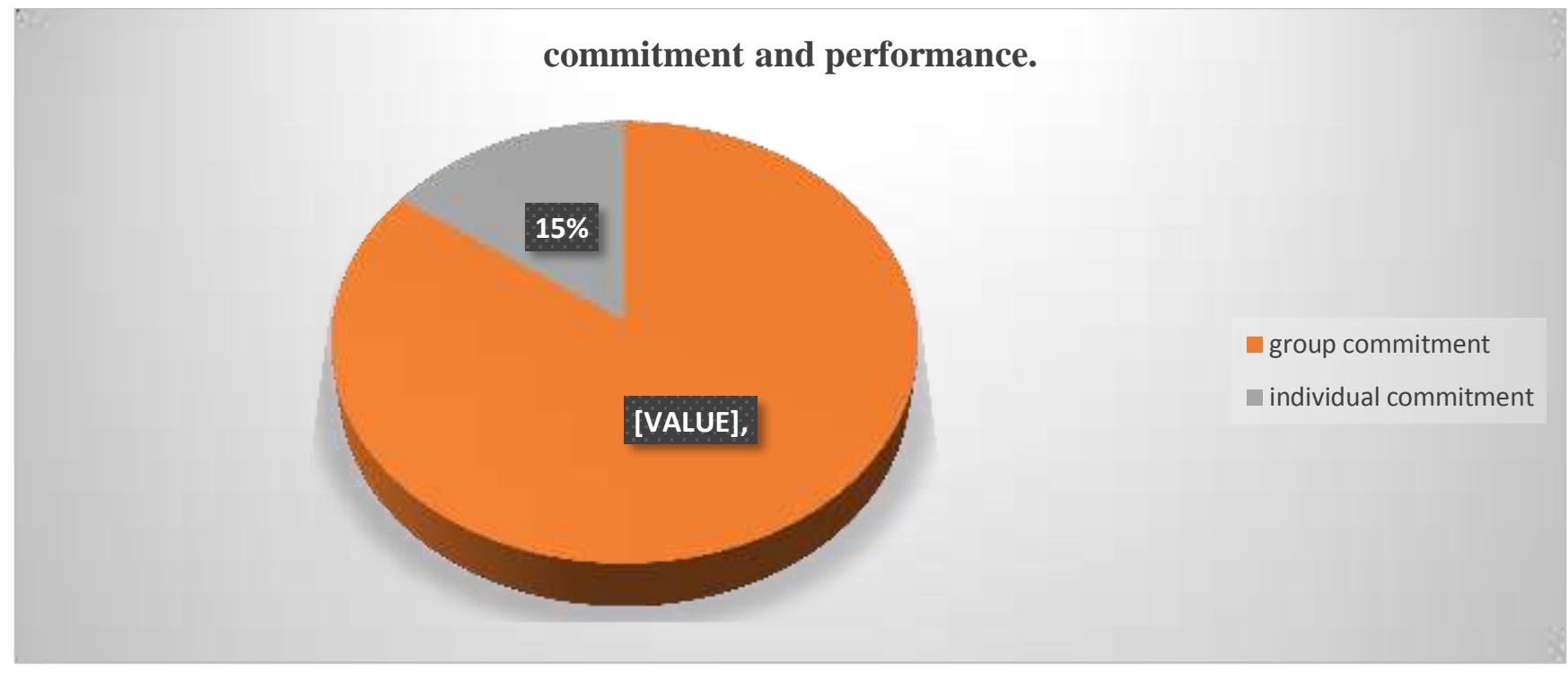

Figure 1: Response Rate on commitment and performance

The question sought to establish the respondents' views on effects of team work commitment on performance in schools in Nairobi city county.

Table 1: How commitment influences group productivity

\begin{tabular}{|l|l|l|l|}
\hline & Question & Yes & No \\
\hline 1. & Commitment in our group is open and honest. & $200(87 \%)$ & $30(13 \%)$ \\
\hline 2. & Do you commit yourself effectively in your work? & $167(72 \%)$ & $63(28 \%)$ \\
\hline 3. & $\begin{array}{l}\text { Do group members decide to resolve various issues pertaining } \\
\text { to commitment without necessarily involving the group leader. }\end{array}$ & $130(57 \%)$ & $100(43 \%)$ \\
\hline 4. & Are group members proud to be part of your team? & $200(87 \%)$ & $30(13 \%)$ \\
\hline
\end{tabular}

Source: Researcher 2021.

The above clearly show what ${ }^{[25]}$ identified in his research on group productivity. His research established that group productivity is directly proportional to group's commitment, more studies point out that teamwork affects commitment. They all established that when people work in groups, they tend to be more motivated since they have a common ground and tasks are broken down easily. On the other hand, the question on how members resolve issues had an almost equal number of employees taking each side. This means that resolving issues in an institution is not an easy task, ${ }^{[7]}$. Most group members also feel more comfortable when working in teams since they get to address issues together, this improves their commitment, ${ }^{[26] .}$

\section{Leadership and performance}

\begin{tabular}{|l|l|l|l|}
\hline & Question. & Yes & No \\
\hline 1. & $\begin{array}{l}\text { Have you participated in a workshop pertaining to commitment in } \\
\text { the last year? }\end{array}$ & $202(88 \%)$ & $28(12 \%)$ \\
\hline
\end{tabular}

Source: Researcher 2021 
International Journal of Advances in Scientific Research and Engineering (ijasre), Vol 7 (11), November -2021

Table 2: Table on leadership and performance

\begin{tabular}{|l|l|l|l|l|l|}
\hline Specific Statement & Strongly agree & \multicolumn{1}{|c|}{$\begin{array}{c}\text { Moderately } \\
\text { agree }\end{array}$} & $\begin{array}{c}\text { Neither agree } \\
\text { not disagree }\end{array}$ & $\begin{array}{c}\text { Moderately } \\
\text { disagree }\end{array}$ & $\begin{array}{c}\text { Strongly } \\
\text { disagree }\end{array}$ \\
\hline $\begin{array}{l}\text { School Administrators and } \\
\text { other stakeholders are always } \\
\text { up to task. }\end{array}$ & {$[113-49 \%]$} & {$[32-14 \%]$} & {$[13-6 \%]$} & {$[16-7 \%]$} & {$[56-24 \%]$} \\
\hline $\begin{array}{l}\text { Group members get } \\
\text { communication on the school } \\
\text { mission and vision constantly. }\end{array}$ & {$[67-29 \%]$} & {$[35-15 \%]$} & {$[44-19 \%]$} & {$[23-10 \%]$} & {$[61-27 \%]$} \\
\hline $\begin{array}{l}\text { Each member is passionate } \\
\text { and is engaged in the } \\
\text { realization of the school } \\
\text { objectives. }\end{array}$ & {$[\mathbf{1 6 8 - 7 3 \% ]}$} & {$[\mathbf{1 2 - 5 \% ]}$} & {$[10-4 \%]$} & {$[\mathbf{1 0 - 4 \% ]}$} & {$[\mathbf{3 0 - 1 3 \% ]}$} \\
\hline $\begin{array}{l}\text { Leaders in our school always } \\
\text { enhance growth and } \\
\text { professionalism among the } \\
\text { staff. }\end{array}$ & {$[\mathbf{1 9 5 - 8 5 \% ) ]}$} & {$[\mathbf{2 0 - 9 \% ]}$} & {$[\mathbf{5 - 2 \%}]$} & {$[\mathbf{0 - 0 \%}]$} & {$[\mathbf{1 0 - 4 \% ]}$} \\
\hline
\end{tabular}

Source: Researcher 2021

The above table clearly shows that school administrators are always up to task together with other stakeholders. A $49 \%$ representing 113 members strongly agreed on this and 14\% representing 32 members moderately agreed on the same. It was only $6 \%$ of the members who neither agreed nor disagreed and 16 members representing $7 \%$ moderately disagreed. Surprisingly, 56 members strongly disagreed with the statement. On the issue of communication, it was realized that no common ground was realized since members were evenly distributed across all the responses with all responses scoring more than $15 \%$. Also, 168 (73\%) members were passionate and the strongly agreed but only 30 (13\%) strongly disagreed on members passionate to the realization of school objectives. On the issue of the role of leadership and growth of professionalism, 195 (85\% strongly agreed that leaders enhance its growth. It is only $10(4 \% \mathrm{O}$ of the respondents who strongly disagreed.

\section{Descriptive analysis of how Workload influences group productivity}

The objective was to assess and evaluate how workload or amount of workload affect employee performance in schools in Nairobi City County in Kenya. The results were as follows depending on the various questions asked under the topic workload;

On the question on members giving support to one another during task performance, 200 workers agreed that they do get the required support and only 30 disagreed. This led to an $87 \%$ number of workers who said yes and only $13 \%$ of those who said no. the table below represents the other questions asked and how the respondents responded to them.

Table 3: How workload influences group productivity

\begin{tabular}{|l|l|l|l|}
\hline & Question & Yes & No \\
\hline 1. & Do you receive support from group members when needed? & $200(87 \%)$ & $30(13 \%)$ \\
\hline 2. & $\begin{array}{l}\text { Have you experienced improved morale while working with your } \\
\text { group? }\end{array}$ & $167(73 \%)$ & $63(27 \%)$ \\
\hline 3. & Is there a difference in working with members in your group? & $188(82 \%)$ & $42(18 \%)$ \\
\hline 4. & $\begin{array}{l}\text { Our team members take into consideration each other's specific } \\
\text { capabilities. }\end{array}$ & $150(65 \%)$ & $80(35 \%)$ \\
\hline 5 & When we work in our teams, we inspire others to do their best. & $200(87 \%)$ & $30(13 \%)$ \\
\hline 6. & We have adequate skills needed to perform tasks effectively. & $123(53 \%)$ & $107(47 \%)$ \\
\hline
\end{tabular}

Source: Researcher 2021 
The above shows that out of $230(100 \%)$ of the respondents, 200 (87\%) agreed to receive support from their fellow members when in need. This was a positive finding which go hand in hand with studies on supporting one another through communicating well when faced with a challenge, ${ }^{[27]}$. The above also shows that there is increased morale when members work together in a group. This was represented by $167(73 \%)$ as opposed to $63(27 \%)$. This means that teamwork improves morale, and this is a confirmation of Al Salman \& Hassan studies on teamwork and morale rate, ${ }^{[5]}$. On the other hand, $123(53 \%)$ agreed that they have skills required to perform various duties. This was slightly more than half and on the other side, 107 (47\%) did not agree. The high number of those who did not agree can be better understood, by looking at the study on resources availability and their effects on the number of members who get trained, ${ }^{[1]}$.

\section{Descriptive analysis of how Training influences group productivity}

The researcher aimed at identifying the relationship between training and employee performance. The researcher posted various questions to the respondents on how training is related to performance. The table below represents the first part of the questions posted to the respondents.

Table 4: How training influences group productivity

\begin{tabular}{|l|l|l|l|l|l|}
\hline Statement & $\begin{array}{l}\text { Strongly } \\
\text { agree }\end{array}$ & $\begin{array}{l}\text { Moderately } \\
\text { agree }\end{array}$ & $\begin{array}{l}\text { Neither agree } \\
\text { not disagree }\end{array}$ & $\begin{array}{l}\text { Strongly } \\
\text { disagree }\end{array}$ & $\begin{array}{l}\text { Moderately } \\
\text { disagree }\end{array}$ \\
\hline $\begin{array}{l}\text { We normally use different forms of } \\
\text { training to keep our skills up to date. }\end{array}$ & {$[145-63 \%]$} & {$[34-15 \%]$} & {$[13-6 \%]$} & {$[28-12 \%]$} & {$[10-5 \%]$} \\
\hline $\begin{array}{l}\text { Our team normally works in flexibility to } \\
\text { be able to adapt to changing needs }\end{array}$ & {$[105-46 \%]$} & {$[34-15 \%]$} & {$[23-10 \%]$} & {$[48-21 \%]$} & {$[20-9 \%]$} \\
\hline $\begin{array}{l}\text { Our team members know what is expected } \\
\text { of them and do it with pride }\end{array}$ & {$[129-56 \%]$} & {$[26-11 \%]$} & {$[12-5 \%]$} & {$[45-20 \%]$} & {$[18-8 \%]$} \\
\hline $\begin{array}{l}\text { Group members shows progressive } \\
\text { improvement in day- to day life activities. }\end{array}$ & {$[149-65 \%]$} & {$[43-19 \%]$} & {$[9-4 \%]$} & {$[18-8 \%]$} & {$[11-5 \%]$} \\
\hline
\end{tabular}

Source: Researcher 2021

The above shows that schools use different forms of training to keep skills up to date. This is well represented by 145 (63\%). It is only $28(12 \%)$ who strongly disagree with it. ${ }^{[28]}$ On methods of assessment and curriculum issues, it is evident that this research is similar to it in a number of ways. On the other side, 149 (65\%) employees strongly agreed that working in team makes members to be progressive in all undertakings. This is a result of motivation they get as a team ${ }^{[12]}$ agrees in his research on effects of motivation on employee performance. Team flexibility did not show a significance connection to employee performance as the table above shows. Also, members know their expectations with $149(65 \%)$ strongly agreeing on the statement on member's expectations and $45(20 \%)$ strongly disagreed. This can be better understood when looking at ${ }^{[29]}$, A study on teamwork paradoxes.

Table 5: Responses on how training influences group productivity

\begin{tabular}{|l|l|l|l|}
\hline & Question & Yes & No \\
\hline 1. & Does your organization consider training as part of the organizational strategy? & $207(90 \%)$ & $23(10 \%)$ \\
\hline 2. & Is the induction training a well-planned process in the organization? & $167(73 \%)$ & $63(27 \%)$ \\
\hline 3. & Does the training offered help to enhance employees versus employer's relationship? & $130(57 \%)$ & $100(43 \%)$ \\
\hline 4. & Does the training offered improve the motivation for employees? & $189(82 \%)$ & $41(18 \%)$ \\
\hline 5. & Does the training offered enables employees to be productive? & $177(77 \%)$ & $53(23 \%)$ \\
\hline 6. & $\begin{array}{l}\text { Does the training course at the organization involve special and specific challenges } \\
\text { faced by teams? }\end{array}$ & $150(65 \%)$ & $80(35 \%)$ \\
\hline 7. & Have you ever been trained in social cohesion? & $160(70 \%)$ & $70(30 \%)$ \\
\hline
\end{tabular}


Source: Researcher 2021

The above clearly shows that training is paramount although it is not well undertaken in schools in Nairobi County. This shows that there is a challenge in how training is conducted, ${ }^{[10]}$. as noted in their studies. Whereas the above shows that training courses enables employees to be productive, training does not really enhance the relationship between employee and employers. This can be understood better because there is no close connection between employee training and employers. ${ }^{[10]}$, Most employees 160 (70\%) agreed that they have been trained in matters to do with social cohesion. This again shows that training should be conducted to all employees to improve results, ${ }^{[10]}$. According to group process theory, training is a key aspect in ensuring that a group remain one and remain focused in its undertaking. On the other issue of training methods used and the training methods preferred by the respondents, the following table clearly shows what the respondents had to say.

Table 6: Methods used in training

\begin{tabular}{|l|l|l|}
\hline & Methods of training preferred & Methods of training used. \\
\hline 1. & In service training $80(35 \%)$ & In service training 152 (66\%) \\
\hline 2. & Off jobs training $150(65 \%)$ & Off job training $78(34 \%)$ \\
\hline
\end{tabular}

Source: Researcher 2021

The above table shows that although many employees prefer off job training method, the organization mostly uses in service training which according to the results, it accounted for $66 \%$ as compared to off job training which accounted for only $34 \%$. This Can be better understood by considering what was found in their research on the effects of training on the performance of employees ${ }^{[11]}$. Administrators like to use in service training as they see it as a way of cutting cost as well as ensuring maximum benefits due to the nature of learning. On the hand, employees dislike the method because they see it as not being sufficient as shown; ${ }^{30]}$

Table 7: How resources were availed for training

\begin{tabular}{|l|l|l|l|l|l|}
\hline Specific Statement & $\begin{array}{l}\text { Strongly } \\
\text { agree }\end{array}$ & $\begin{array}{l}\text { Moderately } \\
\text { agree }\end{array}$ & $\begin{array}{l}\text { Neither agree } \\
\text { nor disagree } \\
\text { disagree }\end{array}$ & $\begin{array}{l}\text { Moderately } \\
\text { disagree }\end{array}$ & {$[14-6 \%]$} \\
\hline $\begin{array}{l}\text { Resources are allocated to training and } \\
\text { development }\end{array}$ & $132-(57 \%)$ & {$[25-11 \%]$} & {$[30-13 \%]$} & {$[29-13 \%]$} \\
\hline $\begin{array}{l}\text { Technology infrastructure has been set } \\
\text { for training }\end{array}$ & {$[99-43 \%]$} & {$[21-9 \%]$} & {$[34-15 \%]$} & {$[12-5 \%]$} & {$[64-28 \%]$} \\
\hline There is hiring of outside trainers & {$[67-29 \%]$} & {$[32-14 \%]$} & {$[56-24 \%]$} & {$[23-10 \%]$} & {$[52-23 \%]$} \\
\hline
\end{tabular}

Source: Researcher 2021

The above table clearly shows that 132 employees accounting for $57 \%$ strongly agreed that there are resources allocated for training. The rest responses were distributed evenly with those strongly disagreeing talking only $13 \%$ which was equal to those undecideds on the issue. It is only $11 \%$ and $6 \%$ who moderately agreed and moderately disagreed respectively. Surprisingly, on the aspect of hiring of outside trainers, the research found that hiring was poorly done with only $29 \%$ strongly agreeing and the rest evenly distributed. This meant that most schools in Nairobi County did not hire or did not see the significance of hiring an external trainer. This was however the opposite of expectations especially in a school setting where external trainers would also be used as agents of motivation, ${ }^{[31]}$.

Table: 8 How often was training carried out

\begin{tabular}{|l|l|l|}
\hline 1. & Weekly & $0(0 \%)$ \\
\hline 2. & Monthly & $5(2 \%)$ \\
\hline 3. & Semiannually & $0(\%)$ \\
\hline 4. & Annually & $225(98 \%)$ \\
\hline
\end{tabular}


On how often the training is carried out in table 8, the researcher found that the training mostly took place semiannually. And it was only in few circumstances that it was undertaken in monthly periods. The table below confirms that it is only in five occasions that training was done on a weekly basis as compared to the $98 \%$ rate of occasions. This points to the fact that most organizations do not have the adequate resources to keep on conducting training but normally undertake training during critical moments like technological change, ${ }^{[30]}$.

\section{Educational Administrators}

On educational administrators, the researcher found profound responses from them concerning various key areas related to employee performance. They are represented below:

Administrators agreed that the main challenge they face in performing their duty was the dynamic changes that occurs in the labor industry ranging from technological advancements as well as diversities among members. One of the administrators said:

... The main challenge affecting our schools is the changing technology. It is rendering most employees jobless as those who cannot get the skills ends up being vulnerable to the organization. As a matter of fact, employees fail to understand the new trends in technological advancement. This poses a challenge when required to step in and attend to a problem requiring technological skills. (respondent 2021)

The question on how educationist enhance performance of a group was responded in various ways. A good number of administrators said that they normally use motivation as the main way to improve performance. One of the respondents had this to say.

To promote group performance, there is need to motivate the employees. Extrinsic motivation helps them to work hard as a group. In my school, I engage my members in visiting game parks during midterms and during holidays. This improves teamwork and enhance performance. (respondent, 2021)

${ }^{[23]}$ The statement concurs with what was identified in the study on the effects of motivation on employee's performance. They both agree that motivation plays a big role in determining performance and they go ahead to even suggest some forms of motivation that can aid in improving employee's performance. They suggest use of incentives and proper working environment. On the question on whether the group gives the administrators adequate chance to improve, most administrators agreed that that is the case in all the organizations and that the employees are patient enough to wait for positive results. This is also what Phina and others ${ }^{[17]}$ found out in their research on teamwork and its effect on employee performance.

The question on stakeholders from the community was also well answered with administrators agreeing to receive stakeholders like Nongovernmental Organization among others. This is what one respondent had to say concerning the stakeholders.

...Yes, we normally get stakeholders who help us in various ways. Others come in to help us pay the non-teaching staff or even help in giving the students some resources. Some stakeholders decide to help in training among others. (respondent 2021) The administrators also agreed that group work continue to play a major role in enhancing performance. One administrator gave an example of how his school was able to perform well and improve in each class due to the members working together.

... It was during those moments when you need an improvement then we decided that all teachers and other members will be working hand in hand. Towards the end, you could see members helping one another without any fear nor doubt. Last year. We posted the best improvement ever seen in this school. For me, there is power in working in groups. Apart from improving performance, it also helps us as administrators in delivering our duties... (researcher, 2021)

The above not only points to the importance of group work and team cohesion but also the results it yields as Richter \&Dawson 2011 suggests.

\section{Regression coefficients}

This study applied the regression analysis model to determine and establish the main effects the independent variables on performance of employees in public schools in Nairobi County.

Table 9: Regression Coefficients.

\begin{tabular}{|l|c|c|c|c|c|}
\hline \multicolumn{1}{|c|}{ Variables } & \multicolumn{2}{|c|}{ Unstandardized Coefficient* } & $\begin{array}{c}\text { Standardized } \\
\text { Coefficients }\end{array}$ & Sig. \\
\hline & B & Std. Error & Beta & & \\
\hline (Constant) & 0.645 & 0.403 & & 4.420 & .000 \\
\hline
\end{tabular}


International Journal of Advances in Scientific Research and Engineering (ijasre), Vol 7 (11), November -2021

\begin{tabular}{|l|c|c|c|c|c|}
\hline Commitment & 0.575 & 0.0236 & 1.432 & 2.540 & .002 \\
\hline Workload & 0.560 & 0.0232 & 1.428 & 2.634 & .003 \\
\hline Training & 0.450 & 0.0220 & 1.368 & 2.750 & .005 \\
\hline
\end{tabular}

The findings show that commitment has a positive association or relationship of $(\beta=0.575$, P-value $=0.002)$ on employee performance. Workload, as a factor affecting employee performance on the other hand had a positive association too of ( $\beta=0.560$, $\mathrm{P}$-value $=0.003$ ) thus confirming studies on employees' performance and teamwork as general, ${ }^{[32]}$. Training too had a positive relation of $(\beta=0.450, \mathrm{P}$-value $=0.005)$ on the performance of employees in schools in Nairobi City County.

\section{CONCLUSION}

In conclusion, the research study confirms that intergroup has a lot of effects when it comes to employee's performance and that there is need to improve the team cohesion if we were to enjoy the benefits of teamwork.

\section{RECOMMENDATIONS}

(i) The findings of this research can be summed up as; commitment has a positive effect on employees' performance. It was also noted that indeed, members of an organization tend to be more committed when working as a team or when working in a group and that there is need for employees to bring efforts together if they are to make maximum productivity in each area of concern and that training is a major aspect in determining performance and they go on to give the recommendations on how organizations should address the issue.

(ii) The researcher came up with the following recommendations after the study was done. There is need for institutions to have a strategic plan to be able to work towards a certain goal while committing themselves in work. This will help employees to remain focused to a certain goal and remain committed into realizing that goal or objective.

There is need for institutions to have a well laid program that guides on how task should be administered to each group in an organization.

There is need for institutions to take into consideration the new trends in job performance and bring in resource persons who will help train the members for better productivity.

(iii) Further Research can be carried out to compare the above findings with other counties in different geographical areas. Other research should also be conducted in other institutions apart from the school institutions in order to see how various organizations would compare.

\section{CONFLICT OF INTEREST}

No potential conflict of interest was recorded by the authors

\section{REFERENCES}

1. Guthirie, J. (2013). Rendering school resources more effective, 45-62.

2. Beal , D. J., Cohen, R., \& Burke, , M. J. (2013). Cohesion and performance in groups: A meta-analytic clarification of construct relation. Journal of Applied Psychology, 88, 989-1004.

3. Casson, A. E. (2013). Fragmented Catholicity and social cohesion: faith schools in a plural society. Oxford: Peter Lang

4. Abdullah, R. (2017). Impact of Teamwork, Esprit De Corps. Team Trust on Employee Performance in Royalindo Expoduta Jakarta Indonesia, 106-113.

5. Al Salman, W., \& Hassan, Z. (2016). Impact of Effective Teamwork on Employee Performance. International Journal of Accounting and Business Management, 76-85.

6. Agarwal, S., \& Adjirackor, T. (2016). Impact of Teamwork on Organizational Productivity in Some Selected Basic Schools in the Accra Metropolitan Assembly. European Journal of Business, Economics, 40-52. 
International Journal of Advances in Scientific Research and Engineering (ijasre), Vol 7 (11), November -2021

7. Kemanci, G. (2018). Investigating the Impact of Esprit De Corps/Team Spirit on Employees Performance in the University of Abuja Teaching Hospital, Gwagwalada, Abuja. Nile Journal of Business, and Economics, 36-47.

8. Rosh .L Offerman, LRand Van Diest, R. (2012), "Too close for comfort? Distinguishing between Team intimancy and Team cohesion', Human Resource Management Review, Vol 22 No. 2 pp116-127

9. Greer, L. L. (2012). Group Cohesion Then and Now. Small Group Research, 655-661.

10. Athar, R., \& Shah, F. M. (2015). Impact of Training on Employee Performance (Banking

11. Casson, A. E. (2013). Fragmented Catholicity and social cohesion: faith schools in a plural society. Oxford: Peter Lang

12. Omolo, P. A. (2015). Effect of motivation on employee performance of commercial banks in Kenya: A case study of Kenya Commercial Bank in Migori County. International journal of human Resource studies, 5(2), 87-103.

13. Austin, R. (2013). Online learning and community cohesion: linking schools. New York: Routledge.

14. Tarique, I., \& Schuler, R. S. (2016). Global talent management: literature review, integrative Framework, and suggestions for further research. Journal of World Business, 122- 133.for Political Socialization Research., 24:23-33.

15. Lawler, E. J., \& Yoon, J. (1996). Commitment in Exchange Relations: Test of a Theory of Relational Cohesion. American Sociological Review, 61, 89-108.

https://doi.org/10.2307/2096408

16. Golov, S. (2014). Ethnic Cultural and National requirements in the education policy of the former soviet union. NewYork: Liang.

17. Phina, N., Arinze, S., Chidi, F., \& Chukwuma, D. (2018). The Effect of Teamwork on Employee Performance: A Study of Medium Scale Industries in Anambra State. International Journal of Contemporary Applied Researches, 174-194.

18. Mbinya, E. (2013, June 25). Factors Affecting Teamwork in export processing Zones in Kenya. Machakos, Kitengela, Kenya.

19. O’Malley M (2000), Creating commitment, John Wiley \& Sons. Chichester

20. Huang, J. L., Ryan, A. M., Zabel, K. L., \& Palmer, A. (2014). team work: A metaanalytic investigation. Journal of Applied Psychology, 162-179.

21. Baard, S.K., Rench, T.A., \& Kozlowski, S.W.J. (2014). Performance adaptation: A theoretical integration and review. Journal of Management, 40(2), 48-99.

22. Griffin, M., Parker, S., \& Mason, C. (2010). Leader vision and the development of adaptive and proactive performance: A longitudinal study. Journal of Applied Psychology, 95(3), 174-182

23. Kiruja, E. K., \& Mukuru, E. (2018). Effect of motivation on employee performance in public middle level Technical Training Institutions in Kenya. IJAME.

24. Mugenda, O. M., \& Mugenda, A. G. (2010). Research Methods, Quantitative and Qualitative Approaches. Nairobi: Acts Press

25. Mohill, L. W. (2016). Group productivity, drive and cohesiveness. Organizational Behavior and Human Performance, 28:2530 .

26. Mbah, S. I. (2014). The effects of teamwork on employees' performance: a study of selected firms in Anambra state Nigeria. British Journal of Advanced Academic Research., 104-118. 
27. Bery, B, Otieno, A, Waiganjo, E. W \& Njeru, A (2015). Effect of Employee Communication on Organization Performance: in Kenya's Horticultural Sector. International Journal of Business Administration, 6(2), 138-145 Retrieved from, http://dx.doi.org/10.5430/ijba.v6n2p138

28. Salam, A. (2010). Issues of objective, content, method and assessment in the development of a relevant curriculum in medical schools. Malaysian Medical Association (MMA) News, 22-24.

29. Yvonne, d. P. (2012). Exploring teamwork paradoxes challenging 21st-century cross-cultural conflict management in a multicultural organizational context. Pretoria, South Africa.: University of Pretoria.

30. Ooko, P. \& Odundo, P. (2015). Impact of Teamwork on the Achievement of Targets in Organizations. In Kenya: A Case of SOS Children's Villages, Elmore. European Journal of Business and Management, 7 (14), 69-77.

31. Chudi, O. C. (2013). Behaviour Organization and Managing the Human Side of Work. New york: Allyn and Bacon Inc.

32. Sapran, A. (2010). Exploiting cooperative movement strengths. Pelancar, 37, 10-11.

C. Author: * Mukhwana, Mildred Nasimiyu: Contact Number:+254 0720146529 Email: $\underline{\text { mmillie657@gmail.com }}$ 